Yu. A. Papaika, orcid.org/0000-0001-6953-1705, O. H. Lysenko, orcid.org/0000-0002-7041-671X, Ye. V. Koshelenko, orcid.org/0000-0003-3600-1550, I. H. Olishevskyi, orcid.org/0000-0001-8573-3366
Dnipro University of Technology, Dnipro, Ukraine, e-mail: papaika@ukr.net

\title{
MATHEMATICAL MODELING OF POWER SUPPLY RELIABILITY AT LOW VOLTAGE QUALITY
}

Purpose. Finding dependence between reliability indexes and power quality. Working out methodology for calculation of reliability index reduction depending on poor power quality based on found dependency.

Methodology. The method of harmonic analysis, the principle of superposition for instantaneous power and the methods of the theory of electric machines. The research objects are distribution processes, processes of transformation, transmitting and consumption of electrical energy in power systems of 6 and $0.4 \mathrm{kV}$ with non-sinusoidal voltage in it. The subjects of the research are reliability indexes of separate power supply system units and its dependency of indexes of electromagnetic compatibility.

Findings. Scientific explanation of equipment reliability index reduction depending on poor power quality in power system. Detection of the effect of non-sinusoidal voltage on the reliability of transformers and cable lines.

Originality. The article analyzes the problems of electricity quality at the moment and describes the importance of solving these problems. The solutions are mainly based on the change in the level of harmonics affecting the power grids, thus improving the quality of electricity. In the work, the analysis of non-sinusoidal voltage influence on power system units' reliability indexes is conducted based on typical city power supply scheme.

Practical value. Finding of regularities of electromagnetic processes' flaws in power system units of 6 and $0.4 \mathrm{kV}$ depending on non-sinusoidal voltage level. Based on researched regularities, the process of reliability index change should be described depending on power quality. The research is conducted for such power system elements as transformers and cable lines. Based on the research, the characteristics of power system units' reliability index change are built depending on the load level.

Keywords: power quality, power supply systems, higher harmonics, reliability, electromagnetic compatibility, modeling.

Introduction. Electrical power system of Ukraine does exist for production, transmitting, distribution and transforming of electrical energy into any other kind of energy like heat, light, mechanical torque and so on. Energy system includes such huge quantity energy sources of electromagnetic interference as: transmitting power lines, switchgears (substations), bus lines, cable lines, electric receivers, automation tools, control, and security.

Electrical power system and power supply system is good environment for generation, distribution and influence of electromagnetic interferences on other system units (electrical energy receivers). Electromagnetic interferences have completely negative influence on power network and they are able to reduce power quality seriously.

Electrical power quality is a complex of properties which determine its influence on electrical power receivers and can be expressed in power quality indexes. Those power quality indexes characterize the level of electromagnetic interferences and can be divided by its frequency, effective value of voltage, shape of curve, symmetry and voltage pulses. Equipment on stations and substations might be affected by those electrical interferences in case of exceeding of determined limits.

Today we encounter two the most important issues such as electrical power quality and power supply reliability. Those problems should be solved in order to provide electrical power supply in required quantity and required quality.

Power supply reliability is a power system ability to provide electrical power energy to its consumers in required quantity according to special conditions of power system.

The main task for the current project is to build characteristics of power system units' reliability reduction depending on level of voltage non-sinusoidality by using developed calculation methodology.

Literature review. In [1] the modeling of reliability indicators of power transformers is performed, to study the influ-

(C) Papaika Yu.A., Lysenko O.H., Koshelenko Ye.V., Olishevskyi I. H. 2021 ence of non-sinusoidality on the reliability of power transformers. [2] describes the development of industrial regions, substantiates the need to ensure adequate quality of electricity for industrial and domestic consumers. In [3] the main ways to achieve a significant level of energy efficiency and energy saving are indicated. In [4] the concept of "economic equivalent of reactive power" is revealed, the need to take into account the influence of voltage changes in the electrical network on the change in active losses from reactive power flows is emphasized. In [5] the modeling of electromagnetic compatibility on the example of technical and mathematical models of drainage systems is carried out. The work [6] considers the resonant modes of operation of power supply systems with non-sinusoidal loads. In [7], frequency and parametric calculations of DC pulse conversion filters for contactless locomotives are performed. In [8], numerical modeling of the phenomena of hydraulic impact and siltation in industrial pump pipelines was carried out. The work [9] considers non-traditional technologies in the mining industry. Work [10] contains mathematical models of physical processes occurring in power supply systems, applicable to the problem being solved. According to [11], 985 companies in the United States account for up to $\$ 45.7$ billion in annual financial losses due to power outages. $\$ 29.2$ billion is related to the manufacturing sector, basic services, and $\$ 13.5$ billion is related to digital organizations. The annual financial loss of the digital sector from the poor quality of the US electricity supply is about $\$ 6.7$ billion. In [12] electromagnetic compatibility of pulse rectifier with pulse-width modulation is performed. In [13] the Kolmogorov-Winner filter used for data prediction is considered, the case without noise is considered. In [14], a generalization of Greg's method based on Bogolyubov's functional hypothesis for states at the end of relaxation processes in the system was developed.

Purpose. The aim of the article is to find the relationship between reliability and electricity quality. Development of a method for calculating the reduction of reliability indicators 
depending on the low quality of electricity based on the found dependence.

The main task of mathematical processing of the collected data is to find and prove hypotheses about the laws of fault distribution, the recovery time of power system units and search for the characteristics of their change over time.

Methods. Indexes of reliability. One of the most important tasks in power industry developing is providing of high reliability of electrical power supply of national economy objects.

Especially, it is important to take into account a reliability factor and its influence on economy developing during projecting stage. By doing that, we can provide certain reliability level of electrical power supply of consumers with the highest economical effect.

At the projecting stage of electrical power systems, three types of reliability tasks should be solved.

1. Determination of optimal reliability level of generation.

2. Determination of optimal reliability level of transmission and distribution of electrical energy and calculated separately for:

- transmission networks with voltage $1150-220 \mathrm{kV}$;

- distribution networks with voltage 110-35-10(6) kV.

3. Determination of optimal reliability level of consumer power supply schemes, for instance, manufacturing enterprises, objects of social and communal spheres, population.

To solve such tasks correctly, it is very important to have adequate assessment of reliability parameters of the main and supporting equipment on power stations and networks.

Under the conception of "power system unit" we should understand any kind of equipment, such as turbine, generator, transformer, circuit breaker, power line or even group of equipment including power unit, power station, step-down substation. Reliability of those power system units can be estimated separately and independently.

From the point of view of reliability theory, four main conditions can be distinguished for power equipment during its exploitation period.

1. Working condition. When the power unit is loaded or works under loaded reservation (the same condition as for loaded power units).

2. Idle reservation. When the power unit is not loaded and is usually turned off. Idle reservation power unit cannot be broken before turning on.

3. Servicing state or under planned repair. During this state, the power system unit is disconnected from power system.

4. Emergency state. When due to breakage, the power system unit is unable to perform specified functions (or its ability is limited). Power system units under this state are usually repaired or replaced with a new one. The process of repair or replacing takes some time. That is why, from the theoretical point of view, work of one power system unit can be considered as a restoration process with an end recovery time.

Reliability of power system unit can be described with such parameters:

- parameter of failure flow, $\lambda^{e m}$;

- average recovery time, $\bar{\tau}^{e m}$;

- possibility of being in such condition, $q$;

- availability factor, $k_{g}$;

- average frequency of scheduled outages, $\lambda^{\text {sch }}$

- average durability of one scheduled outage, $\bar{\tau}^{\text {sch }}$;

- the coefficient of technical use.

In order to estimate the level of reliability we need to find distribution functions of those parameters.

The parameter of failure flow is density of failure probability of a restoring element. At a given moment of time this parameter depends on exploitation durability. From the theory of reliability we know that the Weibul distribution is the simplest distribution function with variable value of parameter of failure flow. The function of parameter of failure flow from time can be described with such expression

$$
\lambda^{e m}(t)=\alpha \cdot \lambda_{0}^{e m} t^{\alpha-1},
$$

where $\alpha$ is the parameter of distribution shape; $\lambda_{0}^{e m}$ is the parameter of failure flow at the initial time.

During the exploitation period which is close to physical deterioration, increasing of unit breakage can be expected. It can be avoided by increasing the frequency of scheduled repairs and services but in this case price of exploitation will be increased.

Recovery time duration and type of damage cannot be predicted before breakage of a certain element occurs. That is why recovery time duration $\tau^{e m}$ is a random value with distribution density $f\left(\tau^{e m}\right)$ and mathematical suspense

$$
M\left[\tau^{e m}\right]=\bar{\tau}^{e m}=\frac{\int_{0}^{\tau_{\text {max }}^{e m}} \tau^{e m} f\left(\tau^{e m}\right) d \tau^{e m}}{\int_{0}^{\tau_{\text {max }}^{e m}} f\left(\tau^{e m}\right) d \tau^{e m}},
$$

where $\tau_{\max }^{e m}$ is maximal recovery time of the element.

Methodology of statistical data collection and processing. The main source for getting adequate assessment of power units' reliability is statistical data on unit emergency conditions and scheduled outages. By using mathematical algorithms of processing gathered data we can determine reliability indexes based on observations.

The main task for mathematical processing of gathered data is finding and proving hypotheses about failures distribution laws, units' recovery time of power system and finding characteristics of changing those with time.

According to that, the whole process of statistical data collecting and processing can be divided in such steps:

- data collecting, systematization and grouping by influencing factors;

- statistical estimation of the main reliability indexes, building of statistical estimation of distribution and statistical assessments accuracy;

- mathematical hypotheses proposing and proving distribution laws.

Such methodology of statistical data processing allows us to find all data needed for power supply system assessment with relatively high accuracy for practical calculations.

To perform such calculations, all statistical data should include:

- total quantity of the equipment of certain type;

- grouping by years of operation beginning, exploration period from the very first sample produced;

- technical parameters of the equipment;

- failure and recovery moments of the equipment, scheduled outages for whole observation period;

- short characterization of working environment before failure moments;

- total failure quantity of the equipment and total idle duration grouped by observation years;

- total scheduled outage quantity and its total duration.

Results. Finding a relationship between reliability and power supply quality.

To define the level of influence on reliability indexes, firstly, we need to calculate reliability indexes during normal conditions of the power system.

By using principle scheme of city power system supply we are going to calculate reliability indexes at 3 different points.

Firstly, we need to build substitution scheme for the scheme represented in Fig. 1. The required scheme is represented in Fig. 2.

In order to make calculations easier we can simplify the scheme with standard formulas. In Table 1 input data for power supply scheme are represented. By using them we are able to calculate reliability indexes at three different points of the 


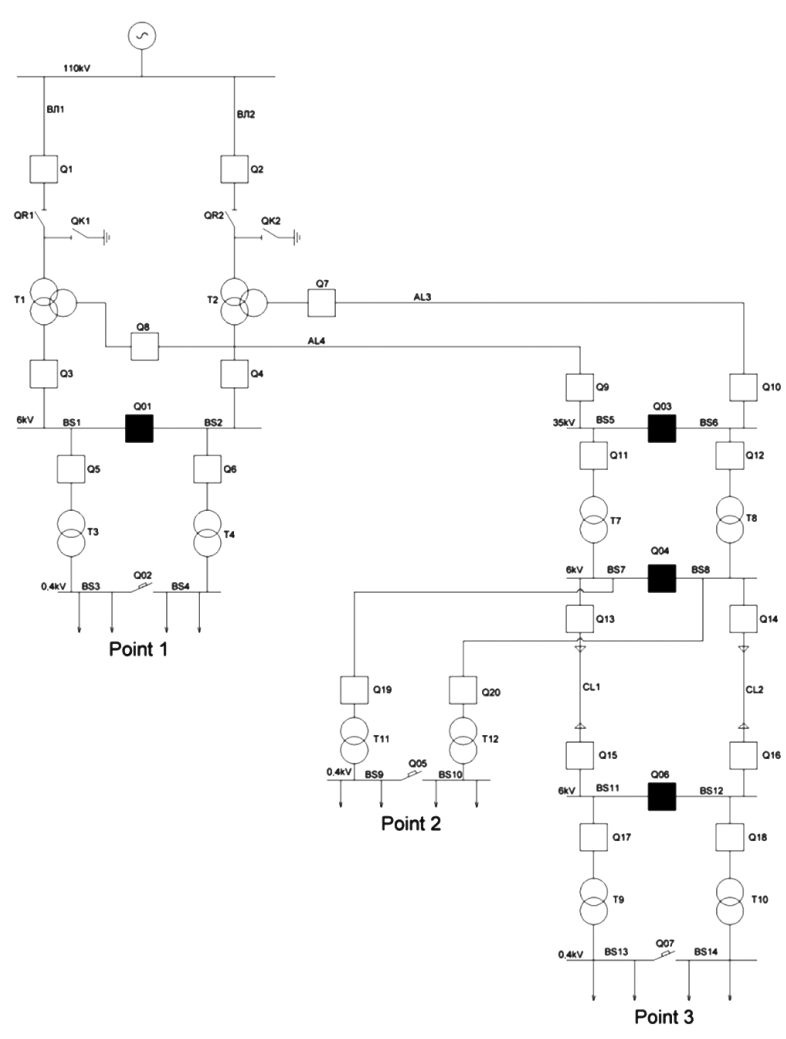

Fig. 1. Principle scheme of city power system supply

scheme. For calculation of reliability indexes at any point of the scheme, we need to know such statistical data as average failing frequency, which shows how many times certain element can be decreased per year and average recovery time, which shows how much time it needs to be repaired or substituted.

We need to find reliability indexes at some points step by step. All series-connected elements should be summed accordingly to the formula below, in order to perform the first simplification of the scheme.

After calculations, reliability indexes at three points of the scheme are found. Anyway all the results are based on statistical data and can be different from real ones. In order to understand influence of higher harmonics on reliability indexes of the power system we have to make assumption that the results are calculated for the system with pure sinusoidal signal on any level of the power system.

The next assumption is that all higher harmonics are generated from low side of power system $0.4 \mathrm{kV}$ and come through the transformers $6 / 0.4 \mathrm{kV}$ to higher sides of power system. We do the research only for harmonics number $3,5,7$ and 11 just because those types of harmonics are the most widespread in power systems of Ukraine and they have the highest magnitude and, therefore, the highest influence and damage. The main objects of the research were transformers $6 / 0.4 \mathrm{kV}$ of all types which are still used in power systems in order to understand their ability to withstand influence of higher harmonics and because they are close to the higher harmonics sources and cable lines next to them. By the way, all the research studies were provided not only for all types of transformers $6 / 0.4 \mathrm{kV}$, but we had three different configurations of the power system and maximum/minimum modes of the power system.

Calculation of transformers' reliability index reduction. We need to recalculate the given non-sinusoidal coefficient on $0.4 \mathrm{kV}$ side to higher one and calculate its influence on other power system units as well as to find reliability reduction of those power units affected by higher harmonics.

First of all, we need to build a substitution scheme of the power supply system based on the scheme represented in Fig. 1.

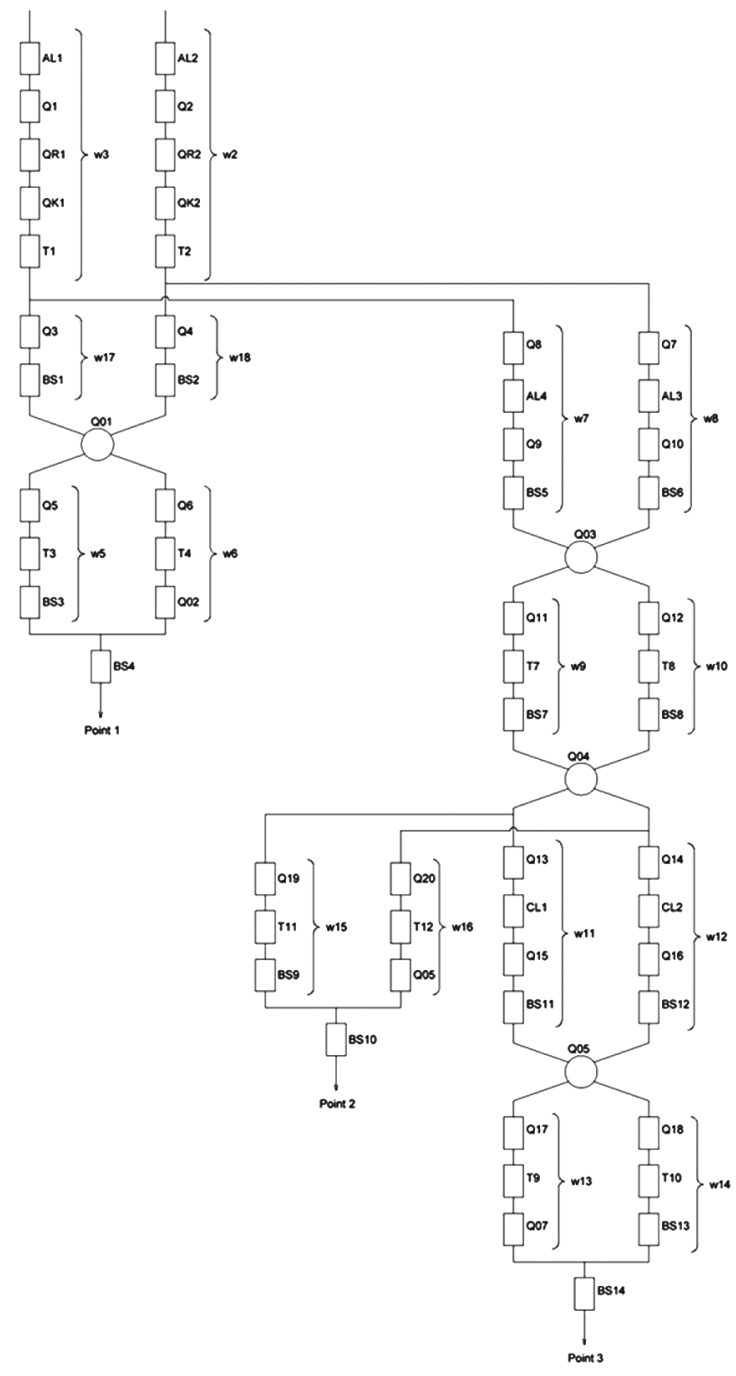

Fig. 2. Substitution scheme of power system supply of the city

Table 1

Input data for providing reliability index calculations

\begin{tabular}{|c|c|c|c|}
\hline No & Name of the element & $\begin{array}{l}\text { Average failing } \\
\text { frequency } \omega \\
\quad\left(\text { year }^{-1}\right)\end{array}$ & $\begin{array}{c}\text { Average } \\
\text { recovery time } \\
\tau \text { (hours) }\end{array}$ \\
\hline 1 & High-voltage switch $110 \mathrm{kV}$ & 0.02 & 20 \\
\hline 2 & Separator $110 \mathrm{kV}$ & 0.01 & 10 \\
\hline 3 & $\begin{array}{l}\text { Three-winding transformer } \\
110 / 35 / 6 \mathrm{kV}\end{array}$ & 0.03 & 30 \\
\hline 4 & High-voltage switch $6 \mathrm{kV}$ & 0.022 & 11 \\
\hline 5 & Sectional switch $6 \mathrm{kV}$ & 0.022 & 11 \\
\hline 6 & Transformer $6 / 0.4 \mathrm{kV}$ & 0.05 & 8 \\
\hline 7 & Sectional switch $0.4 \mathrm{kV}$ & 0.05 & 4 \\
\hline 8 & High-voltage switch $35 \mathrm{kV}$ & 0.02 & 20 \\
\hline 9 & Sectional switch $35 \mathrm{kV}$ & 0.02 & 20 \\
\hline 10 & Transformer $35 / 6 \mathrm{kV}$ & 0.03 & 25 \\
\hline 11 & Cable lines $6 \mathrm{kV}$ & $0.1($ per km) & 15 \\
\hline 12 & Air line $35,110 \mathrm{kV}$ & 0.08 (per km) & 6 \\
\hline 13 & Bus sections $6 \mathrm{kV}$ & $\begin{array}{l}0.03 \text { (per one } \\
\text { connection) }\end{array}$ & 3.5 \\
\hline 14 & Bus sections $35 \mathrm{kV}$ & $\begin{array}{l}0.02 \text { (per one } \\
\text { connection) }\end{array}$ & 4 \\
\hline 15 & Bus section $0.4 \mathrm{kV}$ & 0.007 & 3 \\
\hline
\end{tabular}


Moreover, in order to provide calculations we have to take into account such amendments as:

- all the transformers in power systems are always loaded by $70 \%$ of its apparent power;

- all the lines are loaded to the maximum allowed level of load.

In order to find impedances of the elements we need to adjust our scheme parameters to basic conditions firstly.

After finding the impedance for the whole scheme of the power supply system we are able to find the non-sinusoidal coefficient at point $K_{3}$ by recalculating non-sinusoidal coefficient on $0.4 \mathrm{kV}$ side through the impedances of affected elements. In order to understand how higher harmonics influence reliability of the power system, all calculations should be provided for 10 transformers of the most widespread types, such as: OT-40; OT-63; OT-100; OT-160; OT-250; OT-400; OT-630; OT1000; OT-1600; OT-2500. The value of the non-sinusoidal coefficient on $0.4 \mathrm{kV}$ side changes from 1 to $12 \%$, which is maximally allowed non-sinusoidal coefficient level according to standards.

Although the non-sinusoidal coefficient of $12 \%$ is allowed by GOST, some values for separate higher harmonics should be higher than allowed limits in order to get such value. For example, maximally allowed limit for $3^{\text {rd }}$ harmonic is $5 \%, 5^{\text {th }}$ $-6 \%, 7^{\text {th }}-5 \%, 11^{\text {th }}-3.5 \%$. As we can see, in our case, in order to get total value of the non-sinusoidal coefficient equal to $12 \%$ all higher harmonics are much higher than the determined limits $[1,15]$.

The non-sinusoidal coefficient at point $K_{3}$ can be found by recalculating of determined values at the table above through the impedances of power system elements by using a simple formula.

$$
K_{U 3}=\frac{\left(\frac{X_{*_{S}} \cdot X_{*_{T 6(2)}}}{X_{*_{S}}+X_{*_{T 6(2)}}}\right)}{X_{*_{T 6(1)}}+\left(\frac{X_{*_{S}} \cdot X_{*_{T 6(2)}}}{X_{*_{S}}+X_{*_{T 6(2)}}}\right)} \cdot K_{U 1}
$$

The above formula gives us the value of the non-sinusoidal coefficient on high voltage side. By using this formula we can get both the total value of the non-sinusoidal coefficient on high voltage side and the non-sinusoidal coefficient of separate harmonics.

After finding the value of the non-sinusoidal coefficient on higher side, we can calculate extra heating caused by higher harmonics in power system units very easily.

In order to find the value of extra heating caused by higher harmonics we need to know such values:

- normal operation temperature of power system unit;

- nominal loses in power system equipment caused by pure sinusoidal signal;

- additional loses in power system equipment caused by higher harmonics.

The normal operation temperature of power system transformer is around 45 Celsius degree. Nominal loses in power system transformer can be found in reference literature and, for example, for transformer OT-40 active power loses are around $1.28 \mathrm{~kW}$. But extra loses cannot be found in reference literature and should be calculated for each case. The formula is represented below

$$
\Delta P_{n}=\Delta P_{n o m} \cdot \rho \cdot \sum_{n=2}^{n} \Lambda_{n} U_{n x}^{2},
$$

where $\Delta P_{\text {nom }}$ is nominal loses caused by pure sinusoidal signal, $\rho$ is the index of loses. For transformers it can be calculated like $\rho_{T}^{H H}=\frac{0.6}{U_{S C}^{2}}$, where USC is short circuit voltage of the transformer, $\Lambda_{n}$ is the coefficient of harmonic loses and its value depends on the number of higher harmonic, $\Lambda_{n}=\frac{1}{n \sqrt{n}}$; $U_{n x}$ is higher harmonic value of voltage.

As we know, additional loses in the power system equipment can cause additional heating which has very negative influence on the equipment. Its reliability can be reduced rapidly due to faster insulation aging.

Related insulation shortage can be calculated by using formula.

$$
\Delta T=0.086 \cdot \Delta \tau+\left(\frac{(0.086 \cdot \Delta \tau)^{2}}{2}\right),
$$

where 0.086 is the parameter of Montizinger, which is based on amendment that every 8 Celsius degrees of isolation overheating above nominal value, reduces its operational period by 2 times, $\Delta \tau$ is insulation overheating caused by higher harmonics.

After the value of insulation overheating is found, it can be simply converted into reliability index which can show the influence of higher harmonics on reliability of power system. We can find reliability index value by using such function [4]

Actually that function of reliability index is converted from Arrenius function. Arrenius function shows us insulation shortage depending on insulation temperature by using wellknown 8-degree rule. In function represented in Fig. 3 insulation life time ( $Y$ axe) is substituted by reliability indexes. In our function the same 8-degree rule works, which means that for each 8 Celsius degree of insulation overheating its reliability reduces by 2 times. According to statistical data, almost $80 \%$ of cases of transformers failing happen due to insulation breakage. However, such function of reliability indexes works not for all kind of equipment, but only for equipment with insulation (transformers, cable lines, electric drives).

Functions of transformers' life time and reliability index reduction. In Fig. 4 transformers 6/0.4 life time reduction depending on harmonics level is presented for variant 1 - point 1 . In Fig. 5 transformers 6/0.4 life time reduction depending on harmonics level is presented for variant $1-$ point 2 . Total reliability reduction of power supply at Point 1 depending on harmonics level for Variant 1 is presented in Fig. 6.

For non-sinusoidal coefficient equal to $12 \%$ on low-voltage side, which is the maximum allowed value by GOST, reliability index reduction of the transformer OT-2500 is $6.76 \%$. It is about 1.2 years of total life time reduction of the transformer.

Reliability index reduction differentiates from point to point. For example, for the transformer OT-2500, total reliability index reduction at point 2 is smaller than the results of reliability index reduction at point 3 and differ by $18 \%$; the results at point 1 are much smaller than the results of reliability index reduction at point 2 and in this case they differ by $93.5 \%$.

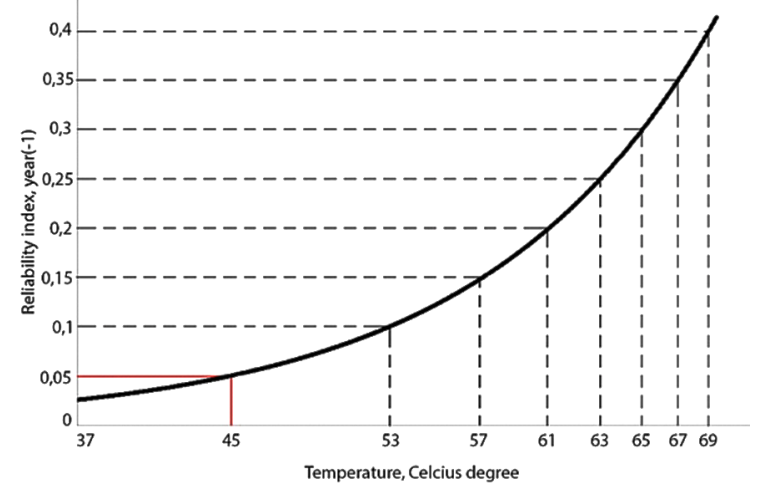

Fig. 3. Function of reliability index depending on equipment temperature 


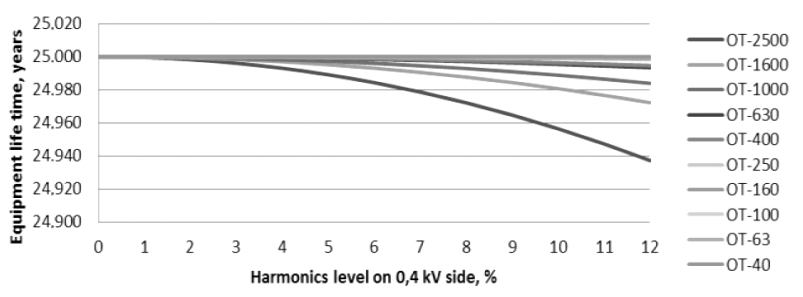

Fig. 4. Transformers 6/0.4 life time reduction depending on harmonics level. Variant 1 - Point 1

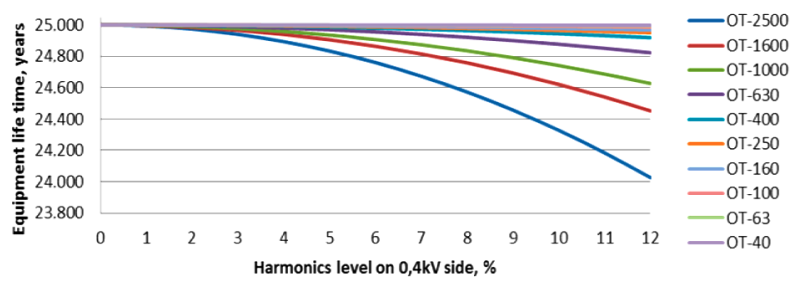

Fig. 5. Transformers 6/0.4 life time reduction depending on harmonics level. Variant 1 - Point 2

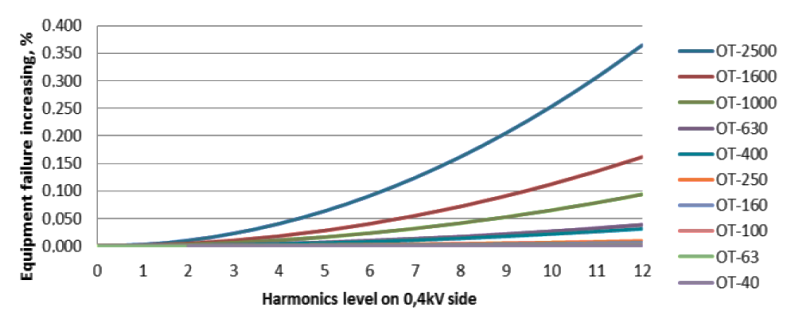

Fig. 6. Total reliability reduction of power supply at Point 1 depending on harmonics level. Variant 1

Calculation of reliability index reduction of cable lines $6 \mathrm{kV}$. Higher harmonics have significant influence on cable lines' life time reduction. With high level of higher harmonics or high value of the non-sinusoidal coefficient, cable lines get older much faster than with pure sinusoidal signal. It happens due to extra heating of cable line caused by those higher harmonics as well as by increasing of ionization processes in it.

For calculation of insulation extra heating of cable line caused by non-sinusoidal signal coming through that, we have to use special thermal substitution scheme displayed in Fig. 7.

Fig. 7 shows the following: $T_{C}$ - temperature of cable line conductors; $T_{S}$ - temperature of surrounding environment; $P_{C}$ - active power loses in cable line conductors; PIS - active power loses in isolation cover cable's cores; $S_{I S}, S_{C . L .}, S_{G}-$ thermal resistances of cable's insulation, covering layers and ground.

Insulation loses are need to be taken into account only for cable lines with nominal voltage $6 \mathrm{kV}$ and higher. Loses in metallic covering layers do not need to be taken into account at all

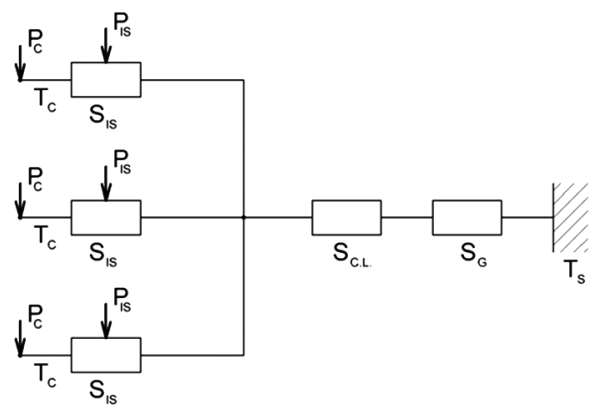

Fig. 7. Thermal substitution scheme of three-core cable line, middle voltage value and laying underground because in case of three-core cable line, they are less than about 2 per cent of total active power loses in conductors. mula

Extra heating of cable lines can be calculated by using for-

$$
\Delta \tau=\theta_{c r} \cdot \sum_{v=2}^{n} I_{v}^{2} \cdot(0.187+0.532 \cdot \sqrt{v}),
$$

where $\theta_{c v}$ is overheating of cable lines caused by active power loses;

$$
\theta_{\tilde{n} v}=3 P_{c . n o m} \cdot\left(S_{I S}+S_{C . L .}+S_{G}\right)=3 I_{\text {nom }}^{2} \cdot R_{c} \cdot\left(S_{I S}+S_{C . L .}+S_{G}\right),
$$

where $P_{c . n o m}$ is active power loses in conductors for nominal operation mode or with nominal value of current Inom flowing through it, W.

$$
P_{c . n o m}=I_{\text {nom }}^{2} \cdot R_{c},
$$

where $I_{\text {nom }}^{2}$ is load current of cable line, $\mathrm{A} ; R_{c}$ - resistance of conductors for maximally allowed temperature of conductors $T_{\text {c.max }}, \mathrm{Ohm} / \mathrm{m}$.

$$
R_{c}=R_{c(20)}\left[1+\alpha_{1} \cdot\left(T_{c \cdot \max }-20\right)\right],
$$

where $R_{c(20)}$ is resistance of conductors for $20{ }^{\circ} \mathrm{C}, \mathrm{Ohm} / \mathrm{m}$; $\alpha_{1}=0.004^{\circ} \mathrm{C}^{-1}$ is the coefficient of thermal resistance.

In order to get values of cable line overheating, all we need to do is to put the data from Table 2 into formulas above. To provide the calculation, we took maximally allowed value of current flowing through it for a long period of time. Values of higher harmonics are still the same and coming from low-voltage side, $0.4 \mathrm{kV}$.

After finding the value of cable line overheating caused by higher harmonics, we can simply convert it into reliability index by using same methodology. The function for converting value of overheating into reliability index is represented in Fig. 8.

High voltage cable lines in our power system are placed near Point 3. All higher harmonics are generated from lowvoltage $0.4 \mathrm{kV}$ side, coming through the transformer to higher side $(6 \mathrm{kV})$; after that they are still able to come through cable lines and other power system units causing different kind of problems. We choose only one kind of cable line AVVN $(3 \times$ $\times 120)$ and its capacity is constant during all calculations. In order to make results much more comparable we make an

Table 2

Cable line parameters for AVVN (3x120)

\begin{tabular}{|c|c|c|c|c|}
\hline $\begin{array}{c}I_{\max }, \\
\mathrm{A}\end{array}$ & $\begin{array}{c}\sigma_{I S}, \\
{ }^{\circ} \mathrm{C} \cdot \mathrm{m} / \mathrm{W}\end{array}$ & $\begin{array}{c}\sigma_{C . L .}, \\
{ }^{\circ} \mathrm{C} \cdot \mathrm{m} / \mathrm{W}\end{array}$ & $\begin{array}{c}\sigma_{G}, \\
{ }^{\circ} \mathrm{C} \cdot \mathrm{m} / \mathrm{W}\end{array}$ & $\begin{array}{c}R_{c(20)}, \\
\mathrm{Ohm} / \mathrm{km}\end{array}$ \\
\hline 242 & 3.5 & 5.25 & 1.2 & 0.35 \\
\hline$\Delta, \mathrm{mm}$ & $\Delta_{1}, \mathrm{~mm}$ & $\Delta_{C L}, \mathrm{~mm}$ & $D, \mathrm{~mm}$ & $\mathrm{~L}, \mathrm{~m}$ \\
\hline 3.4 & 1.2 & 2.4 & 31.8 & 0.8 \\
\hline
\end{tabular}

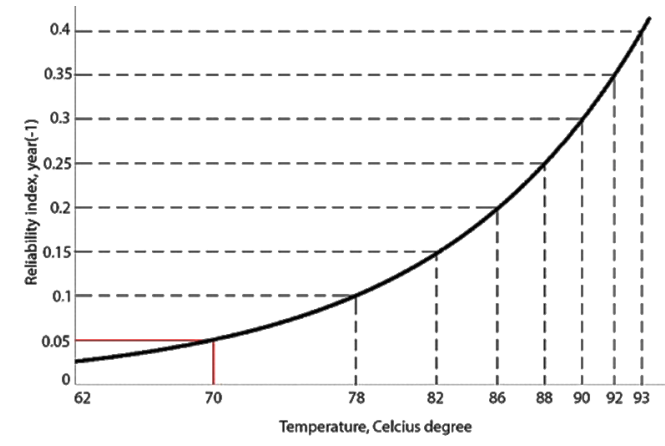

Fig. 8. Function of reliability index depending on equipment temperature, for insulation type $A$ 
amendment that current value coming through the cable lines is always constant. It means that regardless of connected kind of transformer, regardless of a period of the day, current is always equal to $242 \mathrm{~A}$, which is maximally allowed value for such type of cable line.

Minimum mode of the power supply system means significant reduction in power supply demands. Usually, every power supply system encounters with shortage of power demands annually. For example, power supply demands are much less in summer period than in winter. During winter period, a lot of electrical energy is needed for heating.

In our case, for minimum mode of power supply system power demands are less by three times of maximum. Thus the power of short circuit on high voltage bus bars was reduced from 10000 to $3000 \mathrm{MVA}$, all the transformers work with $25 \%$ of its apparent power and cable lines and high-voltage air lines are loaded by $30 \%$ of their total capacity. There are still three variants of power supply system configurations and three points of research, 12 values of non-sinusoidal coefficient on low-voltage $0.4 \mathrm{kV}$ side, which ranges from 1 to $12 \%$, 10 types of oil transformers with theirs apparent power from 40 to $2500 \mathrm{kVA}$ and 2 high-voltage cable lines which provide power to Point 3.

As total power supply system impedance was reduced because of changes in power system configurations, the influence of higher harmonics was reduced a bit. For variant 2, the power supply reliability index of Point 3 was increased to $5.98 \%$ in case of series connection of cable line 1 and step-down transformer OT-2500 and $8.12 \%$ for the cable line 2 .

One more time total power supply system impedance was reduced because of changes in power system configuration that is why the results for variant 3 went down again. The power supply reliability index of Point 3 was increased to $5.68 \%$ in case of series connection of cable line 1 and step-down transformer OT-2500 and $7.73 \%$ for cable line 2.

Conclusions. To sum up the results of calculation, we can say that transformers are not extremely sensitive to the influence of higher harmonics. For the non-sinusoidal coefficient equal to $12 \%$ on low-voltage side, which is the maximum allowed value by GOST, reliability index reduction of the transformer OT-2500 is $6.76 \%$. It is about 1.2 years of total life time reduction of the transformer.

Moreover, not only transformers' impedance influences higher harmonics penetration, but total power system impedance is of huge influence as well. For example, for the transformer OT-2500, total reliability index reduction at point 2 are smaller than the results of reliability index reduction at point 3 and differ by $18 \%$; the results at point 1 are much smaller than the results of reliability index reduction at point 2 and in this case they differ by $93.5 \%$. So, we can notice that power system's impedance has much significant influence on higher harmonics penetration than transformers' impedances. That is why, by substituting high-voltage transformers 35 and $110 \mathrm{kV}$ we could reduce total power supply system impedance value and, as a result, we have got smaller values of reliability indexes reduction for Variant 3 of calculations by $11.85 \%$.

We have determined the influence of higher harmonics on power supply system reliability. All the calculations were based on two kinds of power supply system units such as transformers and cable lines. There were two modes of power system like maximal and minimal and for each of them we had 3 types of power system configurations. The main difference between variants of configuration is total power supply system impedance. Such a parameter as impedance of the system plays significant role in prevention of higher harmonics penetration. The smaller that value is, the less damage higher harmonics can cause to the system. It was proved by placing the same types of step-down transformers into different point of power system. As Point 1 has the smallest power supply system impedance, the worst cases of reliability reduction are in the range from 0.13 to $0.36 \%$. For point 2 the worst cases are in the range from 4.72 to $5.56 \%$. But the most affected of higher harmonics is Point 3 due to series connection of two power supply system units, which are extremely sensitive to higher harmonics influence. So, that is why, the worst cases of power supply reliability reduction for this point are in the range from 52.44 to $57.44 \%$.

In our calculations all higher harmonics sources were placed on the low-voltage side and the range of THD was from 1 to $12 \%$, which is maximally allowed by GOST. However, in order to get value of such THD, some values of higher harmonics should be higher than the limits displayed in GOST.

Mostly, higher harmonics penetration ability depends on impedance of affected equipment. The step-down transformer OT-40 is not affected by higher harmonics at all because its impedance value is extremely high and blocks all higher harmonics coming on high-voltage side. The situation is completely different for the step-down transformer OT-2500, which has comparatively small value of impedance. So, in case of THD of $12 \%$ on low voltage side, THD on high-voltage side is usually up to $2.77 \%$. Such THD value is allowed on voltage level $6-10 \mathrm{kV}$, but, as our power supply system is maximally loaded in the first part, even such value can cause huge reliability reduction of power system units. For example, cable lines $6 \mathrm{kV}$ are more sensitive to higher harmonics influence. For series connection with the transformer OT-2500, cable line 2 is significantly affected by higher harmonics and its total reliability reduction is $50.68 \%$ in case of non-sinusoidal coefficient on low-voltage side equal to $12 \%$. It means that in this case cable line has lost about 10 years of its life time.

All of the represented graphics show us function of financial loses depending on higher harmonics value (THD) on low-voltage side $0.4 \mathrm{kV}$. As we see, with increasing voltage THD, the financial loses are getting higher.

\section{References.}

1. Papaika, Yu., Pivnyak, G., \& Zhezhelenko, I. (2018). Energy efficiency of power supply systems: monograph. Dnipro: Dnipro University of Technology.

2. Sobolev, V., Bilan, N., Dychkovskyi, R., Caseres Cabana, E., \& Smolinski, A. (2020). Reasons for breaking of chemical bonds of gas molecules during movement of explosion products in cracks formed in rock mass. International Journal of Mining Science and Technology, 30(2), 265-269.

3. Pivnyak, G., \& Dychkovskyi, R. (2017). Energy Saving and Efficiency: Technological, Economical and Social Challenges. In: Advanced Engineering Forum: monograph. Zurich: Trans Tech Publication Ltd.

4. Papaika, Yu., Pivnyak, G., \& Zhezhelenko, I. (2016). Estimating economic equivalent of reactive power in the systems of enterprise power supply. Naukovyi Visnyk Natsionalnoho Hirnychoho Universytetu, (5), 62-66.

5. Papaika, Yu., Rogoza, M., Lysenko, O., Rodna, K.S., \& Jakimec, S. N. (2019). Estimation of probability of technical and economic model of drainage installation in electromagnetic compatibility problems. Visnyk Kremenczuckogo Nacionalnogo Universitetu imeni M. Ostrogradskogo, 4/2019(117), 131-137.

6. Dychkovskyi, R., Vladyko, O., Maltsev, D., \& Caseres Cabana, E. (2018). Some aspects of the compatibility of mineral mining technologies. Neki vidovi sličnosti u tehnologijama rudarenja mineralnih sirovina. Rudarsko Geolosko Naftni Zbornik, 33(4), 73-82

7. Papaika, Y., Kosobudzki, G., Rogoza, M., \& Lysenko, O. (2018). Frequency and Parametric Characteristics of Direct Current Pulse Conversion Filter of a Contactless Locomotive. $14^{\text {th }}$ Selected Issues of Electrical Engineering and Electronics (WZEE). https://doi.org/10.1109/WZEE.2018.8748987.

8. Ghavrish, A., \& Shevtsova, O. (2015). The hydraulic impact and alleviation phenomena numeric modelling in the industrial pumped pipelines. In: Power Engineering, Control and Information Technologies in Geotechnical Systems, (pp. 143-153). London: Taylor \& Francis Group. ISBN 978-1-138-02804-3. 
9. Pivnyak, G., Vagonova, O., \& Prokopenko, V. (2017). Scientific Approaches to the Development of Economic Relations between Landowners and Mining Companies. In: $\mathrm{Ad}$ vanced Engineering Forum, (pp. 1-12). Zurich: Trans Tech Publication Ltd.

10. Pivnyak, G., Dychkovskyi, R., Cáceres Cabana, E., Bobyliov, O, \& Smoliński, A. (2018). Mathematical and Geomechanical Model in Physical and Chemical Processes of Underground Coal Gasification. Non-Traditional Technologies in the Mining Industry. In: Solid State Phenomena, (pp. 1-16). Zurich: Trans Tech Publication Ltd.

11. Kosobudzki, G., \& Florek, A. (2017). EMC Requirements for Power Drive Systems, Power Electronics and Drives, 2(2), 127-135. https://doi.org/10.5277/ped170207.

12. Lenoch, V., Masek, Z., Cermak, D., \& Schejbal, V. (2018). Electromagnetic Compatibility of Pulse Rectifier with Pulsewidth Modulation. $28^{\text {th }}$ International Conference Radioelektronika. https://doi.org/10.1109/RADIOELEK.2018.8376352. 13. Gorev, V., Gusev, A., \& Korniienko, V. (2019). Investigation of the Kolmogorov-Wiener filter for treatment of fractal processes on the basis of the Chebyshev polynomials of the second kind. Ceur Workshop Proceedings, 2353, 596. Retrieved from http://ceur-ws.org/Vol-2353/paper47.pdf.

14. Gorev, V. N., \& Sokolovsky, A. I. (2017). The generalization of the Grad method in plasma physics. Condensed Matter Physics, 20(2), 23001. Retrieved from http://www.icmp.lviv. ua/journal/zbirnyk.90/23001/art23001.pdf.

15. Golovchenko, A., Pazynich, Y., \& Potempa, M. (2018). Automated monitoring of physical processes of formation of burden material surface and gas flow in blast furnace. Solid State Phenomena, 277, 54-65. https://doi.org/10.4028/www. scientific.net/SSP.277.54.

\section{Математичне моделювання надійності електропостачання при низькій якості напруги}

\section{Ю. А. Папаӥка, О. Г. Лисенко, С. В. Кошеленко, І. Г. Олішевський}

Національний технічний університет «Дніпровська політехніка», м. Дніпро, Україна, e-mail: papaika@ukr.net

Мета. Знаходження залежності між показниками надійності та якістю електроенергії. Розробка методики розрахунку зниження показників надійності в залежності від низької якості електроенергії на основі знайденої залежності.

Методика. Метод гармонічного аналізу, принцип суперпозиції на миттєву потужність і методи теорії електричних машин. Об'єктами дослідження є процеси розподілу, перетворення, передачі та споживання електричної енергії в енергосистемах 6 та 0,4 кВ із несинусоїдальною напругою в ній. Предметом дослідження є показники надійності окремих блоків системи електропостачання та їх залежність від показників електромагнітної сумісності.

Результати. Наукове пояснення зниження показників надійності обладнання в залежності від низької якості електроенергії в енергосистемі. Виявлення впливу несинусоїдальності напруги на показники надійності трансформаторів і кабельних ліній.

Наукова новизна. У роботі дано аналіз проблем якості електроенергії на даний момент і описується важливість вирішення цих проблем. Рішення грунтуються, головним чином, на зміні рівня гармонік, що впливають на енергосистеми, і таким чином покращується якість електроенергії. У роботі проводиться аналіз впливу несинусоїдальної напруги на показники надійності блоків енергосистеми на основі типової міської схеми електропостачання.
Практична значимість. Знаходження закономірностей недоліків електромагнітних процесів у блоках енергосистеми 6 та 0,4 кВ залежно від рівня несинусоїдальності напруги. Виходячи із досліджуваних закономірностей, процес зміни показників надійності повинен бути описаний як залежність від якості електроенергії. Дослідження проводяться для таких елементів енергосистеми, як трансформатори та кабельні лінії. На основі дослідження будуються характеристики зміни показників надійності енергосистем залежно від рівня його навантаження.

Ключові слова: якість електроенергї, системи електропостачання, вищі гармоніки, надійність, електромагнітна сумісність, моделювання

\section{Математическое моделирование надежности электроснабжения при низком качестве напряжения}

\section{Ю. А. Папаика, А. Г. Лысенко, Е. В. Кошеленко, И. Г. Олишевский}

Национальный технический университет «Днепровская политехника», г. Днепр, Украина, e-mail: papaika@ukr.net

Цель. Нахождение зависимости между показателями надежности и качества электроэнергии. Разработка методики расчета снижения показателей надежности в зависимости от низкого качества электроэнергии на основании найденной зависимости.

Методика. Метод гармонического анализа, принцип суперпозиции на мгновенную мощность и методы теории электрических машин. Объектами исследования являются процессы распределения, преобразования, передачи и потребления электрической энергии в энергосистемах 6 и 0,4 кB с несинусоидальным напряжением. Предметом исследования являются показатели надежности отдельных блоков систем электроснабжения и их зависимость от показателей электромагнитной совместимости.

Результаты. Научное объяснение снижения показателей надежности оборудования в зависимости от низкого качества электроэнергии в системе. Выявление влияния несинусоидальности напряжения на показатели надежности трансформаторов и кабельных линий.

Научная новизна. В работе дан анализ проблем качества электроэнергии на данный момент и описывается важность решения этих проблем. Решения основываются, главным образом, на изменении уровня гармоник, которые влияют на энергосистему, и таким образом улучшается качество электроэнергии. В работе приводится анализ влияния несинусоидального напряжения на показатели надежности блоков энергосистемы на основе типовой городской схемы электроснабжения.

Практическая значимость. Нахождение закономерностей недостатков электромагнитных процессов в блоках 6 и $0,4 \mathrm{kB}$, в зависимости от уровня несинусоидальности напряжения. Исходя из исследованных закономерностей, процесс изменения показателей надежности должен быть описан как зависимость от качества электроэнергии. Исследования приводятся для таких элементов энергосистемы, как трансформаторы и кабельные линии. На основании исследования строятся характеристики изменения показателей надежности энергосистем в зависимости от уровня нагрузки.

Ключевые слова: качество электроэнергии, системь электроснабжения, высшие гармоники, надежность, электромагнитная совместимость, моделирование

Recommended for publication by S. I. Vypanasenko, Doctor of Technical Sciences. The manuscript was submitted 30.10.20. 